\title{
Yrittäjyyden ja resurssien käytön muutos eteläpohjalaisilla maitotiloilla 2000-luvun alussa
}

\author{
Marjo Latva-Kyyny ${ }^{1), 2)}$, Seppo Vehkamäki ${ }^{1)}$, Matti Ylätalo ${ }^{1)}$, Matti Ryhänen ${ }^{2)}$ \\ ${ }^{1)}$ Helsingin yliopisto, Taloustieteen laitos, PL 27, 00014 Helsingin yliopisto \\ ${ }^{2)}$ Seinäjoen ammattikorkeakoulu, Ilmajoentie 525,60800 Ilmajoki \\ marjo.latva-kyyny@helsinki.fi, seppo.vehkamaki@helsinki.fi,matti.ylatalo@helsinki.fi, \\ matti.ryhanen@seamk.fi
}

\section{Tiivistelmä}

Artikkelin tavoitteena oli tarkastella maidontuottajien yrittäjyyttä ja resurssien käyttöä sekäa näissä tapahtuneita muutoksia vuosien 2003 ja 2009 välillä. Lisäksi tavoitteena oli tarkastella millaisia yrittäjäryhmiä löytyy resurssien ja yrittäjyyden suhteen.

Tutkimuksen kohderyhmänä olivat Etelä-Pohjanmaan sekä Pohjanmaan alueeseen kuuluva Kyrönmaan seutukunnan maidontuotantotilat. Tutkimuksessa käytettiin vuonna 2003 ja vuonna 2009 hankittuja aineistoja. Molemmat aineistot hankittiin postikyselyllä. Vuoden 2009 kyselyn saaneista yrittäjistä osa oli vuoden 2003 kyselyn saaneita yrittäjiä, minkä lisäksi otosta täydennettiin satunnaisotannalla. Lopullisessa aineistossa vuonna 2003 oli 191 tilaa ja 258 tilaa vuonna 2009. Tutkimusote oli kvantitatiivinen ja aineiston analysoinnissa käytettiin ensi sijassa faktori- ja ryhmittelyanalyysiä.

Tutkimuksessa yrittäjyyttä tarkasteltiin maitotilayrittäjien työhön liittyvien arvojen, maatilaa koskevan tavoitteellisuuden ja yrittäjyysmotivaation avulla. Tarkastelu tehtiin faktorianalyysin avulla. Merkittävimmiksi faktoreiksi osoittautuivat yrittäjän oma osaaminen, tuotannon jatkuvuus, sosiaalinen arvostus, yrityksen kasvu, haasteellisuus, itsenäinen työ, vapaa-aika ja karjan kehittäminen. Suuria muutoksia yrittäjyydessä vuosien 2003 ja 2009 välillä ei kuitenkaan löytynyt.

Resurssien osalta tutkimuksen tulokset osoittavat keskimääräisen viljelmä- ja karjakoon kasvaneen tarkastelujaksolla. Suurin muutos oli tapahtunut maidon keskituotoksessa, joka kasvoi lähes 10 \%. Suurissa karjakokoluokissa maidon keskituotos oli pieniä karjakokoluokkia suurempi. Myös nuorten yrittäjien osuus viljelijöistä oli hieman kasvanut ja sen mukana yleissivistävän ja ammatillisen koulutuksen taso.

Maitotiloilla oli investoitu aktiivisesti, sillä vain viidellä prosentilla kyselyyn vuonna 2009 vastanneista tiloista ei oltu investoitu viimeisen viiden vuoden aikana. Tiloilla oli investoitu erityisesti koneisiin, rakennuksiin ja peltoon. Näihin investointikohteisiin aiotaan myös lähitulevaisuudessa panostaa eniten. Voimakkaasti tuotantoaan aikoo laajentaa $10 \%$ yrittäjistä samanaikaisesti, kun $9 \%$ yrittäjistä aikoo luopua maataloustuotannosta. Laajentamista eniten rajoittaviksi tekijöiksi yrittäjät nimesivät pellon saatavuuden, vallitsevan maatalouspolitiikan, ajan riittävyyden ja riskin suuruuden.

Yrittäjätoimintaa tutkittiin ryhmittelyanalyysillä. Ryhmittelyanalyysin muuttujina käytettiin yrittäjyyden kuvaamisessa faktorianalyysissä saatuja faktoripisteitä sekä yrittäjiä että resurssia kuvaavina muuttujina yrittäjien ikää, ammatillista koulutusta, kokemusta tilanpidosta, peltopinta-alaa, lehmien lukumäärää ja keskituotosta, yrittäjien jatkoaikomuksia, puolisoiden osallistumista tilan töihin, ulkopuolisten työntekijöiden käyttöä ja sukupolvenvaihdoksen ajankohtaisuutta. Vuoden 2009 aineistosta saatu ryhmittelyanalyysin tulos poikkeaa vuoden 2003 tuloksesta, koska vuoden 2009 ryhmissä resurssit ja yrittäjyys kuvasivat yrittäjätoimintaa selkeämmin kuin aikaisempana tarkasteluajankohtana. Lisäksi vuoden 2009 ryhmissä kävi ilmi yrittäjien elinkaaren vaikutus tuloksiin siten, että yrittäjät voitiin nimetä jatkajiin, kehittäjiin, nykytuotannolla jatkaviin ja jäähdyttelijöihin.

Asiasanat: yrittäjyys, maatilayrittäjä, maidontuotanto, faktorianalyysi, ryhmittelyanalyysi 


\section{Johdanto}

Yrittäjyyttä voidaan tutkia monesta eri näkökulmasta (Davidsson 2004). Aina kuitenkin yrittäjyyden eri määritelmissä on jollain lailla mukana henkilö, yrittäjä, joka kantaa vastuun yrittämisestä. Peltosen (1986, s. 32, 36-37) mukaan yrittäjyys on ajattelu-, toiminta- ja suhtautumistapa, joka ilmenee ihmisen uskomuksissa, teoissa ja tunneilmaisuissa. Se liittyy toimintaan, jolla on tavoitteet. Koirasen ja Peltosen (1995, s. 26) lähikäsitteet yrittäjyydelle ovat aloitekyky, myönteinen työasenne, työhalu, määrätietoisuus, menestymishalu, vastuun kantaminen, halu ottaa riskejä, luovuus, kekseliäisyys ja aktiivisuus. Yrittäjyyteen ja yrittäjäksi ryhtymiseen vaikuttavat monet tekijät, jotka Huuskonen (1995, s. 51-88) jakaa kolmeen ryhmään, jotka ovat yleiset taustatekijät, henkilötekijät ja tilannetekijät. Keskeisesti yrittäjyyteen kuuluvat myös henkilötekijät, jotka ovat elämänkatsomus, arvot, asenteet ja motivaatio.

Yrittäjyys on tärkeä ominaisuus maatalousyrittäjille. Heidän toimintaympäristönsä muuttuu jatkuvasti esimerkiksi maatalouspoliittisten muutosten vuoksi, siten maatalousyrittäjät joutuvat jatkuvasti miettimään maatilansa tavoitteita, kehittämistä ja jatkuvuutta. Heidän on mukautettava yritystoimintansa vastaamaan toimintaympäristön asettamia uusia vaatimuksia. Tämä voi merkitä muutoksia tuotannon voimaperäisyyteen tai resurssien suuntaamiseen. Niinpä maatalousyrittäjät joutuvat muutoksen myötä arvioimaan yrittäjyyttään ja siihen vaikuttavia tekijöitä uudelleen.

Artikkelin tavoitteena on analysoida, miten yrittäjyys ilmenee maidontuotantotiloilla ja millaisia muutoksia siinä on tapahtunut vuosien 2003 ja 2009 välillä. Yrittäjyyttä tarkastellaan yrittäjyysmotivaation, työn arvostuksen ja tavoitteellisuuden näkökulmista. Tavoitteena on myös tarkastella maitotilojen resurssien käyttöä ja siinä tapahtuneita muutoksia. Resurssien osalta tarkastelun kohteena ovat myös lähitulevaisuuden kehittämiskohteet ja laajentumista rajoittavat tekijät. Lisäksi tavoitteena on analysoida yrittäjätoimintaa yrittäjyyden ja resurssien käytön avulla ja kuvata näiden muutosta vuosien 2003 ja 2009 välillä.

\section{Aineisto ja menetelmät}

Artikkelin kohderyhmänä ovat Etelä-Pohjanmaan maitotilat. Tutkimusaineisto hankittiin postikyselynä, jonka tilojen valinta suoritettiin satunnaisotantana. Maidontuottajille lähetetyn laajan kyselylomakkeen avulla pyrittiin kartoittamaan yrittäjien ominaisuudet, keskeiset tuotantoresurssit sekä yritystoimintaa, maatilan elinkaaren vaihetta, tilanpidon jatkuvuutta ja yrittäjyyttä kuvaavat muuttujat. Vuonna 2003 kyselyyn vastasi 191 ja kuusi vuotta myöhemmin 278 viljelijää laajennetun otannan piiriin kuuluneista yhteensä 526 viljelijästä. Vastausprosentit olivat 50 ja 53 . Kyselylomakkeet olivat samansisältöisiä ja kohdejoukko oli sama, joten vertailu vuosien 2003 ja 2009 tulosten osalta on mahdollinen.

Aineiston tilastollinen analyysi suoritettiin SPSS 17.0 -ohjelmistolla. Yrittäjien perustietojen ja resurssien käytön välistä yhteyttä tutkittiin ristiintaulukoinnin avulla. Yrittäjyyttä tutkittiin yrittäjyysmotivaatiota, työn arvostusta ja yritystoiminnan tavoitteellisuutta kuvaavista kysymyksistä laaditulla faktorianalyysillä. Yrittäjätoiminnan tutkimiseen käytettiin ryhmittelyanalyysiä, jossa tarkasteltavina muuttujina olivat yrittäjyysfaktoripisteet yrittäjiä sekä muita resursseja kuvaavina muuttujina: yrittäjien ikä, ammatillinen koulutus, kokemus tilanpidosta, peltopinta-ala, lehmien lukumäärä ja keskituotos, yrittäjien jatkoaikomukset, puolisoiden osallistuminen tilan töihin, ulkopuolisten työntekijöiden käyttö ja sukupolvenvaihdoksen ajankohtaisuus.

\section{Tulokset ja tulosten tarkastelu}

Muuttuvassa toimintaympäristössä maitotilayrittäjien on sopeutettava yritystoiminta uuteen tilanteeseen. Vaihtoehtoja on monia. Tuotantoa voidaan laajentaa, supistaa tai jatkaa ennallaan, vaihtaa tuotantosuuntaa, kehittää sivu- ja liitännäiselinkeinoja, lisätä maatalouden ulkopuolisia tuloja tai lopettaa tuotanto kokonaan. Tämä reagointi toimintaympäristön muutoksiin ilmenee myös tutkimustuloksissa. Maitotilayrittäjien lukumäärä oli tarkastelujaksolla vähentynyt ja keskimääräinen viljelty peltoala ja karjakoko kasvanut. Lisäksi investointeja oli tehty enemmän viimeisen viiden vuoden aikana kuin oli ollut aikomus vuonna 2003. Lisätuloja oli haettu entistä enemmän myös tilan ulkopuolelta, sillä pientä suhteellista kasvua oli nähtävissä sekä puolison käynnissä tilan ulkopuolella töissä että sivuelinkeinoa harjoittavien yrittäjien lukumäärässä.

Yrittäjyyttä tutkittiin faktorianalyysin avulla työn arvostusta, yrittäjyysmotivaatiota ja yrittäjien tavoitteellisuutta koskevilla kysymyksillä. Saadut faktorit voitiin kuvata yrittäjyyden tai yrittäjyysmo- 
tivaation faktoreina. Suurta muutosta näin määritettyjen faktoreiden osalta ei ollut vuosien 2003 ja 2009 tulosten osalta. Pääfaktorit, joille latautui eniten muuttujia, olivat pääosin samoja näiden kahden eri vuoden aineistoissa (taulukot 1ja 2). Vuoden 2009 faktoreista yrittäjyyttä selvästi kuvaavia faktoreita olivat yrityksen kasvu, yrittäjien osaaminen, karjan kehittäminen, tuotannon tehostaminen ja suurimittakaavainen tuotanto. Näille päinvastainen faktori oli vapaa-aika. Yrittäjyyttä motivoivina tekijöinä voidaan kuvata faktoreita jatkuvuus, sosiaalinen arvostus ja haasteellisuus. Yrittäjyyttä kuvaavissa faktoreissa ei ollut tapahtunut juurikaan muutoksia kuuden vuoden aikana toisin kuin resurssien käytössä, jossa oli tapahtunut merkittäviä muutoksia.

Taulukko 1. Vuoden 2003 faktorit ja niille eniten latauksia saaneet muuttujat. Suluissa oleva prosenttiluku kertoo kunkin faktorin selitysosuuden muuttujien konaisvaihtelusta.

\begin{tabular}{|c|c|c|c|c|c|}
\hline 1. Kasvu(25,2 \%) & $\begin{array}{c}\text { Faktori } \\
\text { pisteet }\end{array}$ & $\begin{array}{l}\text { 5. Karjan kehittäminen } \\
(4,2 \%)\end{array}$ & $\begin{array}{r}\text { Faktori } \\
\text { pisteet }\end{array}$ & $\begin{array}{l}\text { 9. Eläinmäärän lisäys ja } \\
\text { riskien minimointi( } 2,7 \%)\end{array}$ & $\begin{array}{c}\text { Faktori } \\
\text { pisteet }\end{array}$ \\
\hline Peltoalan lisääminen & 0,765 & $\begin{array}{l}\text { Korkeampi karjan } \\
\text { jalostusarvo }\end{array}$ & 0,863 & Eläinmäärän lisäys & 0,562 \\
\hline Tilakoon kasvu & 0,720 & Laatupalkintojen saaminen & 0,853 & Riskien minimointi & 0,560 \\
\hline $\begin{array}{l}\text { Keskituotoksen } \\
\text { kasvattaminen }\end{array}$ & 0,670 & & & & \\
\hline 2. Osaaminen(9,5 \%) & & 6. Jatkuvuus(3,5 \%) & & $\begin{array}{l}\text { 10. Uudet ihmissuhteet } \\
(2,5 \%)\end{array}$ & \\
\hline $\begin{array}{l}\text { Ympäristön pitäminen } \\
\text { siistinä }\end{array}$ & 0,716 & Tilanpidon jatkuvuus & 0,794 & $\begin{array}{l}\text { Uusien ihmissuhteiden } \\
\text { hankkiminen }\end{array}$ & 0,627 \\
\hline $\begin{array}{l}\text { Usko omiin } \\
\text { mahdollisuuksiin }\end{array}$ & 0,624 & Tieto maatilan jatkajasta & 0,754 & & \\
\hline $\begin{array}{l}\text { Kyky organisoida } \\
\text { tuotantoa }\end{array}$ & 0,570 & Sukutilan jatkaminen & 0,599 & & \\
\hline 3. Hyvät edu(5,7 \%) & & 7. Vapaa-aika(3,1\%) & & $\begin{array}{l}\text { 11. Itsenäinen } \\
\text { päätöksenteko(2,2 \%) }\end{array}$ & \\
\hline $\begin{array}{l}\text { Mahdollisimman vähän } \\
\text { henkisiä paineita }\end{array}$ & 0,782 & Vapaa-ajan lisääminen & 0,642 & $\begin{array}{l}\text { Mahdollisimman suuri } \\
\text { palkka }\end{array}$ & 0,489 \\
\hline Riittävästi lomaa & 0,637 & $\begin{array}{l}\text { Uudenlaisten koneiden } \\
\text { kokeilu }\end{array}$ & 0,490 & $\begin{array}{l}\text { Itsenäinen } \\
\text { päätöksentekomahdollisuus }\end{array}$ & 0,448 \\
\hline Hyvä eläke & 0,635 & & & & \\
\hline $\begin{array}{l}\text { 4. Sosiaalinen arvostus ja } \\
\text { haasteellisuus }(5,2 \%)\end{array}$ & & 8. Tukipolitiikka(3,0 \%) & & & \\
\hline Luonnonläheisyys & 0,593 & Harjoitettu tukipolitiikka & 0,497 & & \\
\hline $\begin{array}{l}\text { Mahdollisuus kehittää } \\
\text { itseään }\end{array}$ & 0,573 & Investointiavustukset & 0,473 & & \\
\hline $\begin{array}{l}\text { Ympäristön antama tuki ja } \\
\text { arvostus }\end{array}$ & 0,546 & & & & \\
\hline
\end{tabular}


Taulukko 2. Vuoden 2009 faktorit ja niille eniten latauksia saaneet muuttujat. Suluissa oleva prosenttiluku kertoo kunkin faktorin selitysosuuden muuttujien kokonaisvaihtelusta.

\begin{tabular}{|c|c|c|c|c|c|}
\hline 1. Kas vu (29,0 \%) & $\begin{array}{l}\text { Faktori } \\
\text { pisteet }\end{array}$ & $\begin{array}{l}\text { 5. Sosiaalinen arvostus } \\
(4,1 \%)\end{array}$ & $\begin{array}{l}\text { Faktori } \\
\text { pisteet }\end{array}$ & $\begin{array}{l}\text { 8. Tuotannon } \\
\text { tehos taminen }(2,6 \%)\end{array}$ & $\begin{array}{l}\text { Faktori } \\
\text { pisteet }\end{array}$ \\
\hline Peltoalan lisääminen & 0,816 & $\begin{array}{l}\text { Mahdollisuus saada } \\
\text { tunnustusta }\end{array}$ & 0,725 & $\begin{array}{l}\text { Työn rasittavuuden } \\
\text { helpottaminen }\end{array}$ & 0,516 \\
\hline Tilakoon kasvu & 0,785 & $\begin{array}{l}\text { Ympäristön antama tuki ja } \\
\text { arvostus }\end{array}$ & 0,719 & $\begin{array}{l}\text { Yksikkökustannusten } \\
\text { alentaminen }\end{array}$ & 0,384 \\
\hline $\begin{array}{l}\text { Lisäpellon tai vuokrapellon } \\
\text { saatavuus }\end{array}$ & 0,721 & $\begin{array}{l}\text { Itsensä tarpeelliseksi } \\
\text { tunteminen }\end{array}$ & 0,580 & & \\
\hline 2. Osaaminen $(8,0 \%)$ & & $\begin{array}{l}\text { 6. Karjan kehittäminen } \\
(3,9 \%)\end{array}$ & & 9. Ennakoitavuus (2,5 \%) & \\
\hline $\begin{array}{l}\text { Usko omiin } \\
\text { mahdollisuuksiin }\end{array}$ & 0,673 & $\begin{array}{l}\text { Korkeampi karjan } \\
\text { jalostusarvo }\end{array}$ & 0,729 & $\begin{array}{l}\text { Tulevaisuuden helppo } \\
\text { ennakoitavuus }\end{array}$ & 0,411 \\
\hline $\begin{array}{l}\text { Kyky organisoida } \\
\text { tuotantoa ja tilanpitoa }\end{array}$ & 0,661 & $\begin{array}{l}\text { Keskituotoksen } \\
\text { kasvattaminen }\end{array}$ & 0,725 & Harjoitettu tukipolitiikka & 0,399 \\
\hline $\begin{array}{l}\text { Riittävä oma ammattitaito } \\
\text { ja osaaminen }\end{array}$ & 0,649 & & & & \\
\hline $\begin{array}{l}\text { 3. Vapaa-aika ja hyvät edut } \\
(5,8 \%)\end{array}$ & & 7. Haasteellisuus (2,7 \%) & & $\begin{array}{l}\text { 10. Suurimittakaavainen } \\
\text { tuotanto }(2,2 \%)\end{array}$ & \\
\hline Vapaa-ajan lisääminen & 0,671 & $\begin{array}{l}\text { Mahdollisuus kehittää } \\
\text { itseään }\end{array}$ & 0,684 & Eläinmäärän lisäys & 0,677 \\
\hline $\begin{array}{l}\text { Enemmän rahaa } \\
\text { yksityiseen kulutukseen }\end{array}$ & 0,601 & Riittävästi uusia haasteita & 0,573 & $\begin{array}{l}\text { Suuren maitotilan } \\
\text { omistaminen }\end{array}$ & 0,532 \\
\hline $\begin{array}{l}\text { Mahdollisimman suuri } \\
\text { palkka tehdystä työstä }\end{array}$ & 0,568 & & & & \\
\hline 4. Jatkuvuus (4,7 \%) & $\begin{array}{r}\text { Faktori } \\
\text { pisteet }\end{array}$ & & & & \\
\hline Tilanpidon jatkuvuus & 0,826 & & & & \\
\hline Tieto maatilan jatkajasta & 0,710 & & & & \\
\hline Sukutilan jatkaminen & 0,597 & & & & \\
\hline
\end{tabular}

Tutkimuksessa tarkasteltiin myös yrittäjätoimintaa tutkimalla yrittäjyyden ja resurssien välistä riippuvuutta ryhmittelyanalyysilla, jossa ryhmittävinä tekijöinä käytettiin faktorianalyyseillä saatuja faktoripisteitä sekä resursseja ja yrittäjiä kuvaavia muuttujia. Yrittäjätoiminnassa olikin havaittavissa selkeä muutos kuuden vuoden aikana. Vuoden 2003 aineistosta muodostui kolme ryhmää, joiden nimet ovat Taantujat, Ristiriitaiset ja Toimijat. Vuoden 2009 aineiston osalta päädyttiin viiden klusterin ratkaisuun, joihin vaikutti elinkaaren vaihe. Maitotilayrittäjät nimettiin seuraavasti: Jatkaja 1, Jatkaja 2, Kehittäjät, Nykytuotannolla jatkavat ja Jäähdyttelijät. Taulukoissa 3 ja 4 on esitettynä ryhmittelyanalyysissä käytettyjen muuttujien suunta ja voimakkuus keskiarvoon nähden ryhmittäin. Ryhmänimen perässä suluissa oleva luku kertoo yrittäjien suhteellisen osuuden kyseissä ryhmässä. 
Taulukko 3. Vuoden 2003 ryhmittelyanalyysin muuttujien suunta ja voimakkuus keskiarvoon nähden ryhmittäin.

\begin{tabular}{|c|c|c|c|}
\hline Ryhmittelyanalyysin muuttujat & Taantujat (63\%) & Ristiriitaiset (9\%) & Toimijat (28\%) \\
\hline \multicolumn{4}{|l|}{ Yrittäjä ja resurssit } \\
\hline Ikä & ++ & +++ & -- \\
\hline Ammatillinen koulutus & -- & - & +++ \\
\hline Kokonaispeltoala & - & -- & +++ \\
\hline Lehmien lkm & - & -- & ++ \\
\hline Keskituotos & - & -- & ++ \\
\hline Puolison osallistuminen tilan töihin & - & - & + \\
\hline Ulkopuolisten työntekijöiden käyttö & - & -- & +++ \\
\hline Tilanpitoaika & ++ & +++ & --- \\
\hline Sukupolvenvaihdoksen ajankohtaisuus & - & -- & +++ \\
\hline Jatkaa nykyisellään & + & - & -- \\
\hline Laajentaa hieman & + & + & -- \\
\hline Laajentaa voimakkaasti & + & + & - \\
\hline \multicolumn{4}{|l|}{ Yrittäjyys } \\
\hline Kasvu & + & ++ & -- \\
\hline Osaaminen & - & +++ & - \\
\hline Hyvät edut & - & + & ++ \\
\hline Sosiaalinen arvostus ja haasteellisuus & - & +++ & - \\
\hline Karjan kehittäminen & - & +++ & + \\
\hline Jatkuvuus & - & -- & ++ \\
\hline Vapaa-aika & - & +++ & - \\
\hline Tukipolitiikka & + & - & -- \\
\hline Eläinmäärän lisäys ja riskien minimointi & - & + & + \\
\hline Uudet ihmissuhteet & - & -- & + \\
\hline Itsenäinen päätöksenteko & + & -- & - \\
\hline
\end{tabular}

Taulukko 4. Vuoden 2009 ryhmittelyanalyysin muuttujien suunta ja voimakkuus keskiarvoon nähden ryhmittäin. 


\begin{tabular}{|c|c|c|c|c|c|}
\hline Ryhmittelyanalyysin muuttujat & Jatkajat $1(5 \%)$ & Jatkajat $2(23 \%)$ & Kehittäjät (20 \% ) & $\begin{array}{l}\text { Nykytutoannolla } \\
\text { jatkavat (16 \% ) }\end{array}$ & $\begin{array}{c}\text { Jäähdyttelijät (35 } \\
\% \text { ) }\end{array}$ \\
\hline \multicolumn{6}{|l|}{ Yrittäjä ja resurssit } \\
\hline Ikä & --- & -- & -- & + & +++ \\
\hline Ammatillinen koulutus & +++ & ++ & ++ & - & -- \\
\hline Kokonaispeltoala & + & - & +++ & - & -- \\
\hline Lehmien lkm & -- & - & +++ & + & - \\
\hline Keskituotos & -- & - & ++ & + & + \\
\hline Puolison osallistuminen tilan töihin & -- & -- & ++ & ++ & + \\
\hline Ulkopuolisten työntekijöiden käyttö & - & + & +++ & + & -- \\
\hline Tilanpitoaika & -- & -- & -- & - & +++ \\
\hline Sukupolvenvaihdoksen ajankohtaisuus & -- & -- & - & -- & ++ \\
\hline Jatkoaikomus & ++ & - & +++ & -- & -- \\
\hline \multicolumn{6}{|l|}{ Yrittäjyys } \\
\hline Kasvu & ++ & + & +++ & -- & -- \\
\hline Osaaminen & -- & + & ++ & + & - \\
\hline Vapaa-aika ja hyvät edut & -- & + & -- & ++ & + \\
\hline Jatkuvuus & ++ & -- & - & -- & ++ \\
\hline Sosiaalinen arvostus & + & - & + & - & + \\
\hline Karjan kehittäminen & -- & + & + & + & - \\
\hline Haasteellisuus & -- & + & + & -- & + \\
\hline Tuotannon tehostaminen & - & + & ++ & - & + \\
\hline Ennakoitavuus & + & - & - & ++ & - \\
\hline Suurimittakaavainen tuotanto & -- & - & +++ & + & - \\
\hline
\end{tabular}

Verrattaessa vuosien 2003 ja 2009 ryhmittelyanalyyseja voidaan havaita vuoden 2009 tulosten olevan yrittäjyyttä koskevien ennakkokäsitysten mukaisempia kuin vuoden 2003 tulosten. Vuoden 2009 ryhmissä yrittäjien toiminnat ja resurssit käyvät hyvin yksiin yrittäjyyttä kuvaavien muuttujien kanssa. Yrittäätoiminta on tarkastelujaksolla kehittynyt niin, että yrittäjyys ja resurssit ovat realisoituneet aikaisempaa selkeämmin maitotilayrittäjien toiminnassa vuonna 2009. Vuoden 2009 ryhmät olivat kehittäneet toimintaansa yrittäjyyttä kuvaavien faktoripisteiden mukaisesti. Tämä näkyi mm. yrittäjien resurssien käytössä siten, että kasvua arvostavat yrittäjät olivat investoineet ja aikoivat investoida myös jatkossa, kun taas vapaa-aikaa arvostavilla investointiaikomukset olivat vähäisiä. Vuoden 2009 tuloksista oli myös havaittavissa selkeä yritystoiminnan yhteys resurssien käytön ja yrittäjyyden osalta yritystoiminnan elinkaareen.

Maatilojen muuttuminen entistä yritysmäisemmäksi tulee esille myös yrittäjien vastauksista. Vesalan ja Peuran (2002, s. 38) mukaan itsensä nimeäminen yrittäjäksi kertoo yrittäjäidentiteetin vahvuudesta. Sosiaalisen identiteetin teorian mukaan itsekategoriointi liittyy sitoutumiseen. Jos henkilö tahtoo olla ja katsoo olevansa yrittäjä, hän hyväksyy yrittäjyyden itsensä määreenä ja suuntautuu siihen. Vuonna 2009 maitotilayrittäjät nimesivät itsensä aiempaa ajankohtaa useammin yrittäjiksi eri vaihtoehtoisista ammattinimikkeistä.

Merkillepantavaa vuoden 2009 aineiston klustereissa oli Jäähdyttelijöitten suuri osuus (35 \%), kun siihen lisätään vielä Nykytuotannolla jatkavat (16 \%), niin tilaansa eteenpäin vievien Kehittäjien osuus jää suhteellisen alhaiseksi. Vain 20 \% yrittäjistä kuuluu tähän ryhmään. Vuoden 2003 aineistossa tilaansa kehittävien osuus (Toimijat-ryhmä) oli $28 \%$. Absoluuttisina lukuina vastaavat luvut koko perusjoukossa olivat 602 ja 282. Kaikkien maitotilayrittäjien lukumäärä on vähentynyt 34 \% (2178 tilasta 1429 tilaan) tarkastelujaksolla. Eli tilaansa kehittävien yrittäjien osuus on laskenut suhteellisesti enemmän kuin kaikkien maitotilayrittäjien määrä. Tämä tarkoittaisi seuraavan viiden vuoden aikana tilaansa kehittävien yrittäjien lukumäärän alenemista yli puolella, jolloin jäljelle jäisi vajaat 150 tilaansa kehittävää maitotilayrittäjää.

\section{Johtopäätökset}

Ulkopuolisten työntekijöiden käyttö oli tarkastelujaksolla yleistynyt ja tulee mitä ilmeisimmin edelleen kasvamaan. Varsinkin tuotantoaan laajentavat, investointeja suunnittelevat tilat tarvitsevat ulkopuolista työvoimaa kiireaikoina. Jatkossa tullaankin tarvitsemaan ammattitaitoisia, uuden teknologian hallitsevia työntekijöitä yhä enemmän. Miten tähän kysyntään voidaan vastata? Miten saadaan nuoret kiinnostumaan maatalouden vaativasta, mutta vaihtelevasta työstä? 
Investointiaktiivisuus oli Eteläisen seinänaapurien ja Seinäjoen seutukunnan alueilla ollut voimakkaampaa kuin muissa seutukunnissa. Nämä aktiivisten alueiden yrittäjät suunnittelivat investointeja myös tulevaisuuteen muita enemmän. Heille voi kuitenkin tulla vaikeuksia tilansa tasapuolisessa kehittämisessä, koska yrittäjät nimesivät eniten laajentamista rajoittavaksi tekijäksi maatalouspolitiikan lisäksi pellon saatavuuden. Kilpailu pellosta on jo nyt aktiivisilla alueilla kovaa ja se kiristyy edelleen. Pellon kohonnut hinta heikentää myös yrittäjien maksuvalmiutta. Onko aktiivisilla alueilla tilojen kehittäminen ylipäätään mahdollista, jos peltoa ei ole saatavissa?

Pellon saatavuutta vaikeuttaa se, että pellon kysyntä ja tarjonta ovat epätasapainossa. Aktiivisella Eteläisen Seinänaapurin alueella on enemmän Kehittäjiä kuin Jäähdyttelijöitä, kun taas muilla seutukunnan alueilla tilanne on päinvastoin. Aktiivisilla alueilla tämä kiristää kilpailua pellosta, jolloin hintataso edelleen nousee. Muilla alueilla voidaan perustellusti kysyä, mitä tapahtuu tuotannosta luopuvien yrittäjien resursseille, jos niille ei ole kysyntää. Mikäli resurssit jäävät käyttämättä, sillä on merkittävät aluetaloudelliset vaikutukset.

Tulosten mukaan tilaansa kehittävien yrittäjien osuus oli tarkastelujaksolla vähentynyt enemmän kuin maitotilayrittäjien määrä yleensä. Kehityssuunta on huolestuttava, koska tutkimusalue on Suomen maidontuotannon kärkialueita. Tähän samaan ongelmakohtaan liittyy läheisesti myös maidontuotantoa jatkavien yrittäjien alhaiset investointiaikomukset vuonna 2009. Kummallakaan tarkastelluista jatkajaryhmistä ei ollut suuria investointisuunnitelmia. Heidän tilansa olivat pieniä. He edustavat kuitenkin seuraavaa sukupolvea, josta pitäisi löytyä seuraavat maidontuottamista kehittävät yrittäjät, jotta elinvoimainen maidontuotanto voi jatkua maassamme. Toisaalta yrittäjyystaival näillä yrittäjillä on vielä niin tuore, etteivät he vielä ole täysin tiedostaneet, mihin ovat ryhtyneet ja siten tulevaisuuden suunnitelmat ovat selkiintymättömät. Uusi jatkotutkimusaihe olisikin selvittää, miten resurssien siirtoa luopuvilta yrittäjiltä tuotantoaan jatkaville voitaisiin edesauttaa. Mielenkiintoista olisi tutkia myös niitä "jatkajia”, jotka eivät koskaan ottaneet tilaa haltuunsa, jolloin olemassa olevat resurssit siirtyivät toisille yrittäjille tai jäivät käyttämättä. Miksi he eivät ottaneet tilaa haltuunsa ja minkälaiset yrittäjyysasenteet heillä on?

Yrittäjyyden ja resurssien kohtaamisessa on tapahtunut selvä muutos vuodesta 2003 vuoteen 2009. Tiloilla on tilanne vuoden 2003 tarkastelun mukaan koettu ilmeisesti tapahtuneista muutoksista johtuen "kaoottisena” ja tulevaisuus hyvin epävarmana. Epävarmuuden aiheuttajat eivät tehdyn tutkimuksen perusteella käy ilmi, vaan se vaatii erillisen selvityksen. Vuoden 2009 aineistossa yrittäjyyden ja resurssien kohtaaminen on enemmän odotusten mukainen kuin kuusi vuotta aiemmin. Nuoria yrittäjiä edustavista ryhmistä tehdyt päätelmät antavat aiheen sellaiseen johtopäätökseen, että vastaisissa tutkimuksissa tilan sisäiset suuntautumisvaihtoehdot ja tilan toimintaympäristön muutokset ja sen tarjoamat vaihtoehdot tulee tarkemmin ottaa huomioon kuin, mitä nyt on tehty.

\section{Kirjallisuus}

Davidsson, P. 2004. Researching entrepreneurship. ISEN International Studies in Entrepreneurship. Springer. 218 p.

Huuskonen, V. 1995. Yrittäjäksi ryhtyminen. Teoreettinen viitekehys ja sen koettelu. Kaarina: Turun kauppakorkeakoulun julkaisuja. Sarja A-2:1992. 233 s.

Koiranen, M. \& Peltonen, M. 1995. Yrittäjyyskasvatus. Ajatuksia yrittäjyyteen oppimisesta. Tampere: Tammer-Paino Oy. $136 \mathrm{~s}$.

Peltonen, M. 1986. Yrittäjyys. Keuruu: Otavan Kirjapaino Oy. 240 s.

Vesala, M. V. \& Peura, J. 2002. Yrittäjäidentiteetti monialaisilla maatiloilla. Helsingin yliopiston Maaseudun tutkimus- ja koulutuskeskus, Mikkeli. Julkaisuja 78. 95 s. 